\title{
Sodium Iodate Influences the Apoptosis, Proliferation and Differentiation Potential of Radial Glial Cells In Vitro
}

\author{
Xi Chen ${ }^{a, b, c, d}$ Qiyou Lic,d Haiwei Xu ${ }^{c, d}$ Zheng Qin Yin ${ }^{a, c, d}$ \\ aDepartment of Ophthalmology, Chinese People's Liberation Army General Hospital, Beijing, bSchool \\ of Medicine, Nankai University, Tianjin, 'Southwest Hospital/Southwest Eye Hospital, Third Military \\ Medical University, Chongqing, 'Key Lab of Visual Damage and Regeneration \& Restoration of \\ Chongqing, Chongqing, China
}

\section{Key Words}

Differentiation • Radial glial cells • Proliferation • Sodium iodate $\cdot$ TGF- $\beta 1 \cdot$ Wnt/ $\beta$-catenin

\begin{abstract}
Background/Aims: Sodium iodate $\left(\mathrm{NaIO}_{3}\right)$-induced acute retinal injury is typically used as an animal model for degenerative retinal disease; however, how $\mathrm{NaIO}_{3}$ influences the apoptosis, proliferation and differentiation of endogenous retinal stem cells is unknown. Methods: We exposed a radial glial cells (RGCs) line (L2.3) to different $\mathrm{NaIO}_{3}$ concentrations and determined the influence of $\mathrm{NaIO}_{3}$ on apoptosis, proliferation, and differentiation using flow cytometry and immunofluorescence assays. We used a real-time polymerase chain reaction assay to analyze the levels of mRNAs encoding GSK-3 $\beta$, AXIN2, $\beta$-catenin, TGF- $\beta 1$, SMAD2, SMAD3, NOG (Noggin), and BMP4. Results: Cell density decreased dramatically as a function of the $\mathrm{NaIO}_{3}$ dose. $\mathrm{NaIO}_{3}$ increased apoptosis, inhibited mitosis, proliferation, and the $\mathrm{Wnt} / \beta$-catenin pathway. CHIR99021 (Wnt agonist) treatment efficiently reversed the effects of $\mathrm{NaIO}_{3}$ on the apoptosis and proliferation of RGCs. The number of neuronal class III $\beta$-tubulin-positive cells decreased markedly, whereas that of glial fibrillary acidic protein-positive cells increased significantly when RGCs were exposed to $\mathrm{NaIO}_{3}$. During differentiation, the Nog mRNA level decreased and transforming growth factor- $\beta 1$ (Tgf- $\beta 1$ ) and Smad2/3 mRNA levels increased significantly when RGCs were exposed to $\mathrm{NaIO}_{3}$. Conclusion: $\mathrm{NaIO}_{3}$ increased apoptosis, influenced the proliferation of RGCs and drove them toward astrocytic differentiation, likely through inhibition of the Wnt/ $\beta$-catenin and noggin pathways and activation of the TGF- $\beta 1 /$ SMAD2/3 pathway.
\end{abstract}

Copyright (c) 2014 S. Karger AG, Basel

Prof. Zheng Qin Yin and Prof. Haiwei Xu

Southwest Eye Hospital, Southwest Hospital, Third Military Medical University, Chongqing 400038, (China)

Tel. +86-23-68754803, E-Mail qinzyin@aliyun.com; haiweixu2001@163.com 


\section{Introduction}

Age-related macular degeneration (AMD) is the main cause of blindness in developed countries [1]. Similar to retinal dystrophies, Stargardt disease, and some forms of retinitis pigmentosa, AMD is considered a disease of the retinal pigment epithelium (RPE) [2]. Sodium iodate $\left(\mathrm{NaIO}_{3}\right)$-induced loss or degeneration of the RPE serves as a frequently used model of acute retinal injury. In this system, $\mathrm{NaIO}_{3}$ selectively damages the RPE, causing dysfunction of photoreceptors or injuring intraretinal neurons at an early development stage [3].

The retina, a component of the central nervous system (CNS), possesses the potential to self-repair through the activation of endogenous stem cells. Glial cells exhibit stem-celllike properties and generate neurons, glia, or both. The major glial cell type in the retina is Müller glial cells [4]. Compared with the efficiency seen in lower vertebrates, including fish and amphibians, the efficiency of Müller glial cell regeneration is extremely low in mammals, although Müller glial cells represent the primary source of new neurons in mammals [5]. Das et al. isolated Müller glial cells from rats on postnatal (PN) days 10-21 and treated them with FGF2. A subset of these Müller glial cells proliferated to generate neurospheres that displayed characteristic features of neural stem cells (NSCs), including uptake of 5-ethynyl20-deoxyuridine (BrdU) and expression of Sox2, nestin, and Musashi [6]. Further, Müller glial cells that re-enter the cell cycle express the markers of bipolar and photoreceptor cells $[7,8]$. Müller glial cells remain dormant in the adult retina; however, when injured by a neurotoxin and transplanted into the retina, they migrate into all layers of the retina and express the markers of rod photoreceptor, amacrine, and ganglion cells [6]. Taken together, these findings suggest that Müller glial cells may represent mammalian retinal stem cells. Moreover, mature Müller glial cells share several markers with RGCs, including glial fibrillary acidic protein (GFAP) and vimentin [9-11], and the immature Müller glia of zebrafish also express the RGC marker brain lipid binding protein (BLBP) [12].

Müller glial cells are the only glial cells that are derived from the retinal neuroepithelium in the mammalian retina. After injury, astrocyte activation in the brain usually causes glial scar formation, which is referred to as reactive gliosis. Pathological conditions usually activate Müller glial cells [13]. Kiuchi et al. reported that Müller glial cells proliferated on the third day after mice were administered $\mathrm{NaIO}_{3}$; moreover, the ratio of GFAP-positive cells increased markedly for 28 days [14]. Reactive gliosis, which may cause formation of a harmful scar, is thought to have detrimental effects on retinal neurons; however, reactive gliosis provides neuroprotection and participates in tissue repair [15]. Müller glial cells promote tissue repair by phagocytosing the products of neuronal degeneration, such as exogenous particles, cell debris, and hemorrhagic products, particularly those derived from dying photoreceptors [16].

Further, Müller glial cells protect against the excitotoxic effects of excessive stimulation by glutamate by mediating the amidation of glutamate to generate a non-neuroactive compound [17]. These cells protect against reactive oxygen species by synthesizing glutathione that is transferred to neurons [18]. They also secrete neurotrophic factors, including vascular endothelial growth factor (VEGF) [19]. However, overexpression of VEGF may lead to retinal vasculature proliferation that may cause retinal neurodegeneration [20]. There is controversy regarding whether gliosis impedes the recovery of vision after an injury, protects against the formation of a secondary lesion [13], or both.

Thus, the mechanisms that precisely orchestrate the proliferation and differentiation of Müller glial cells remain largely unknown. Therefore, the goal of this study was to define these mechanisms. Radial glia are found in regions of the cortex, cerebellum, spinal cord, and retina, and constitute the major cortex stem cell population in the developing brain [21]. RGCs originate from the neuroepithelium and populate the adult CNS as Müller glial cells in the retina and as Bergmann glia in the cerebellum [22]. Radial glia are NSCs that initially generate neurons and later differentiate into astrocytes during CNS development [23]. Therefore, because of their common origin, we consider RGCs as a valid experimental substitute for Müller glial cells. 
The Wnt/ $\beta$-catenin pathway plays a central role in self-renewal and apoptosis $[24,25]$. Ablation of the expression of $\beta$-catenin [26] or low density lipoprotein receptor-related protein 6 (LRP6) [27] (essential coreceptor in the Wnt/ $\beta$-catenin pathway, whose ligand is recognized as Dickkopf-1 [28]) markedly impairs neural system development. Neural stem cell differentiation is modulated by Noggin and bone morphogenetic protein 4 (BMP4). BMP4 directs the radial glia-like cells to differentiate into astroglia; however, Noggin induces the differentiation of radial glia-like cells into neurons through antagonizing BMP4 activity [29]. In contrast, transforming growth factor- $\beta 1$ (TGF- $\beta 1$ ) acts as an injury-related cytokine associated with astrocyte scar formation in response to brain injury [30]. TGF- $\beta 1$ activates SMAD2/3 transcription factors, which then form a complex with SMAD4 that activates the transcription of target genes [31]. The output of this signaling pathway promotes the differentiation of radial glia-like cells into astrocytes in vitro [32]. Therefore, we investigated the effects of these signaling pathways on the proliferation and differentiation potential of RGCs after $\mathrm{NaIO}_{3}$ treatment in vitro.

In the present study, we established a model system to study $\mathrm{NaIO}_{3}$-induced injury to endogenous retinal stem cells (RSCs) in an attempt to determine the mechanisms underlying the proliferation and differentiation of RGCs.

\section{Materials and Methods}

\section{Culture and differentiation of L2.3 cells}

The L2.3 cells used were a gift from H. Li [33]. Cells were dissected from the forebrains of E14.5 rat embryos without meningeal membranes, which contain a large number of radial glia. The colonies expressed radial glial-markers, that is, brain lipid binding protein 7 (FABP7; also called BLBP), nestin, and vimentin, but not the markers of neurons ( $\beta$-III tubulin) and oligodendrocytes (04). L2.3 cells differentiate to neurons and glia (astrocytes and oligodendrocytes), express the same markers, and exhibit the same differentiation potential as RGCs and NSCs $[33,34]$.

L2.3 cells were grown as floating neurospheres in DMEM/F12 (Invitrogen, USA) supplemented with $25 \mathrm{mM}$ glucose (Sigma-Aldrich, USA), $10 \mathrm{ng} / \mathrm{ml}$ basic fibroblast growth factor (BD Bioscience, USA), $50 \times$ B27 (Gibco, USA), $2 \mu \mathrm{g} / \mathrm{ml}$ heparin (Sigma-Aldrich) and $100 \mathrm{U} / \mathrm{ml}$ penicillin and streptomycin (Gibco) at $37^{\circ} \mathrm{C}$ in a humidified atmosphere containing $5 \% \mathrm{CO}_{2}$. The cultures were passaged without replenishing the culture medium when the neurospheres grew into aggregates of 50-100 cells (usually in 2-3 days). During passaging, the neurospheres and culture medium were transferred into sterilized Eppendorf microfuge tubes and were dissociated into single cells by pipetting them repeatedly in the pipet tip. After centrifuging the solution $(150 \times g / 5 \mathrm{~min})$ and removing the supernatant, the cells were resuspended in an appropriate volume of fresh culture medium.

To induce differentiation, the cells were cultured on polylysine- and laminin-coated coverslips in $50 \times$ B27 containing serum-free medium (DMEM/F12 with $25 \mathrm{mM}$ glucose and $100 \mathrm{U} / \mathrm{ml}$ penicillin and streptomycin) for 7 days. To minimize the influence of exogenous factors, we did not add fetal bovine serum to the medium. These culture conditions and differentiation protocols were modifications of those described by Li et al. [33, 35]. The final concentrations of $\mathrm{NaIO}_{3}$ (Sigma-Aldrich) added to the culture and differentiation medium were $0.5 \mu \mathrm{g} / \mathrm{ml}, 5 \mu \mathrm{g} / \mathrm{ml}$, and $50 \mu \mathrm{g} / \mathrm{ml}$. For the differentiation potential assay, the cells were collected at 7 days after differentiation.

\section{Cell proliferation assay}

After the cells were exposed to $\mathrm{NaIO}_{3}$, the number of cells in each of the three wells was determined. The data represent the mean of three independent experiments. The proliferative potential of L2.3 cells was measured on days 1-3 after $\mathrm{NaIO}_{3}$ treatment. Neurospheres were labeled with $10 \mu \mathrm{M}$ BrdU for $2 \mathrm{~h}$, dissociated into single cells, and cultured on coverslips coated with polylysine and laminin. After attachment for $6 \mathrm{~h}$, the cells were fixed with $4 \%$ paraformaldehyde for $30 \mathrm{~min}$ at $4^{\circ} \mathrm{C}$, incubated in $2 \mathrm{~N} \mathrm{HCl}$ for $30 \mathrm{~min}$ at $37^{\circ} \mathrm{C}$ and processed for BrdU immunostaining after washing with $0.1 \mathrm{M}$ borate buffer for $10 \mathrm{~min}$.

To determine the role of Wnt signaling in the proliferation of RGCs, the Wnt agonist CHIR99021 (3 $\mu \mathrm{M}$; $\mathrm{R} \& \mathrm{D}, \mathrm{USA}$ ) was added to culture media containing different concentrations of $\mathrm{NaIO}_{3}$ on day 1 . 
Fluorescence-activated cell sorting (FACS) analysis of apoptosis, the cell cycle, and differentiation

Neurospheres were dissociated, centrifuged as described above, cooled, and washed twice with phosphate-buffered saline (PBS). All procedures were performed in an ice bath to minimize cell death induced by mechanical injury. The cells were stained with propidium iodide (PI) and Annexin V conjugated to fluorescein isothiocyanate (FITC) for $15 \mathrm{~min}$ at room temperature and were shielded from light. The cell distribution was determined using a FACSCalibur Flow Cytometer (BD Bioscience) and analyzed using the Flowjo software (TreeStar, USA). At least 10,000 cells were analyzed per sample. The experiments were performed in triplicate, and each result represents the mean of three independent experiments.

The cell-harvesting procedure described above yielded consistent results. The cells were fixed after cooling in $70 \%$ ethanol solution for $12 \mathrm{~h}$ and were then stained using the Cycletest ${ }^{\mathrm{TM}}$ Plus DNA Reagent Kit (BD Bioscience). DNA content was determined using a FACSCalibur Flow Cytometer, and the data were analyzed using the ModFit 2.0 software (BD Bioscience). At least 20,000 cells in each sample were analyzed.

To determine the number of cells undergoing differentiation, the cells were trypsinized and collected 7 days after treatment. The cells were fixed in $70 \%$ ethanol solution for $30 \mathrm{~min}$, permeabilized with $0.1 \%$ Triton X-100 (Amresco, USA) for $10 \mathrm{~min}$, and blocked with 3\% bovine serum albumin (BSA, Sigma-Aldrich) and $10 \%$ normal goat serum (Boster, China) for $1 \mathrm{~h}$. The cells were washed three times between procedures. The cells were then incubated with either anti-neuronal class III $\beta$-tubulin (Tuj1) or anti-glial fibrillary acidic protein (GFAP) antibody (BD Bioscience) for $30 \mathrm{~min}$ at $4^{\circ} \mathrm{C}$ and shielded from light. After washing with PBS, the cell numbers were determined using a FACSCalibur Flow Cytometer, and the data were analyzed using the Flowjo software. At least 10,000 cells were analyzed in each sample. Negative control experiments were performed in parallel using antibodies against unrelated proteins (Mouse IgG2a $\kappa$ Isotype Control for Tju1 and Mouse IgG2b $\kappa$ Isotype Control for GFAP; BD Bioscience). All FACS analyses were performed in triplicate, and each result represents the mean of three independent experiments.

\section{Immunocytochemistry and cell counting}

For immunostaining, cells were fixed with $4 \%$ paraformaldehyde for $30 \mathrm{~min}$ at $4{ }^{\circ} \mathrm{C}$, permeabilized with $0.1 \%$ Triton X-100 for $10 \mathrm{~min}$, and blocked with $3 \% \mathrm{BSA}$ and $10 \%$ normal goat serum for $1 \mathrm{~h}$ at room temperature. The cells were incubated with primary antibodies overnight at $4^{\circ} \mathrm{C}$, followed by incubation with secondary antibodies for $1 \mathrm{~h}$ at $37^{\circ} \mathrm{C}$. Nuclei were stained with 4', 6-diamidino-2-phenylindole (DAPI, Beyotime, China). The cells were washed three times with PBS between procedures. Primary antibodies and their dilutions were as follows: mouse anti-BrdU (1:200, Abcam, UK), rabbit anti-BrdU (1:200, Bioss, China), rabbit anti-active Caspase-3 (1:150, Abcam, UK), mouse anti-Tuj1 (1:400; Beyotime), and rabbit anti-GFAP (1:200; Abcam, UK). Secondary antibodies were conjugated to Alexa Fluor ${ }^{\circledR} 488$ (goat anti-mouse IgG, 1:400; Beyotime) or Cy3 (goat anti-mouse IgG, 1:500, Beyotime; goat anti-rabbit IgG, 1:500, Beyotime). Negative control experiments were performed in parallel using normal goat serum instead of the primary antibodies.

The apoptosis of L2.3 RGCs treated with NaIO3 was analyzed by Terminal Deoxy Nucleotidyl Transferase-Mediated Nick End Labeling (TUNEL) assay using an In Situ Cell Death Detection Kit (Roche, Indianapolis, IN). According to the manufacturer' instructions, cells were fixed, permeabilized and incubated with the mixture of enzyme solution (TdT) and Label Solution (fluorescein-dUTP; $1: 9$ ) for $1 \mathrm{~h}$ at $37^{\circ} \mathrm{C}$. The nuclei of the cells were stained with DAPI (Beyotime, China). The cells were washed three times with PBS between procedures.

After immunostaining, the cells were observed and analyzed using a fluorescence microscopy system (Leica, Germany). At least 10 fields were counted for each slide. The number of cells in each field was measured by counting DAPI-positive nuclei. The expression level of each antigen was determined by calculating the ratio of positive cells to the total number of cells. All operations were performed in triplicate, and each result represents the mean of three independent experiments.

\section{Real-time polymerase chain reaction (PCR)}

We analyzed the expression of genes encoding signal transduction proteins by using quantitative (realtime) reverse transcription PCR. The primers used fulfilled all the requirements for real-time PCR primers and were therefore very specific (Table 1). Total RNA was purified using TRIzol reagent (Invitrogen) and quantified using spectrophotometry. After reverse transcription performed using the ReverTra Ace ${ }^{\circledast}$ qPCR RT Kit (Toyobo, Japan), real-time PCR reactions were performed using an ABI PRISM 7900HT System (Applied Biosystems, USA) using the Realtime PCR Master Mix ${ }^{\mathrm{TM}}$ (Toyobo). The volumes used for the PCR 
Table 1. Real-time PCR primers

\begin{tabular}{|c|c|c|}
\hline Gene & Primer sequences $\left(5^{\prime}-3^{\prime}\right)$ & Product length (bp) \\
\hline \multirow[t]{2}{*}{$\operatorname{Tgf}-\beta 1$} & CTGCTGACCCCCACTGATAC (F) & \multirow{2}{*}{90} \\
\hline & CTGTATTCCGTCTCCTTGGTTC (R) & \\
\hline \multirow[t]{2}{*}{ Smad2 } & TAССАСТСТСТССССТGTCAAT (F) & \multirow{2}{*}{194} \\
\hline & GCAAACCTAAGCAGAACCTCTC (R) & \\
\hline \multirow[t]{2}{*}{ Smad3 } & TGGCTACCTGAGTGAAGATGG (F) & \multirow{2}{*}{110} \\
\hline & AGTTATTGTGTGCTGGGGACA (R) & \\
\hline \multirow[t]{2}{*}{ Nog } & GAGATCAAAGGGCTGGAGTTC (F) & \multirow{2}{*}{241} \\
\hline & GCACAGACTTGGATGGCTTAC (R) & \\
\hline \multirow[t]{2}{*}{ Bmp4 } & CCGGATTACATGAGGGATCTT (F) & \multirow{2}{*}{156} \\
\hline & TGGGATGTTCTCCAGATGTTC (R) & \\
\hline \multirow[t]{2}{*}{ Gsk-3ß } & CCTGCCCTCTTCAACTTTACC (F) & \multirow{2}{*}{149} \\
\hline & CCACGGTCTCCAGCATTAGTA (R) & \\
\hline \multirow[t]{2}{*}{ Axin2 } & TACCGCATGGGCAGTAAGAAAC (F) & \multirow{2}{*}{89} \\
\hline & CTCGGGAAATGAGGTAGAGACA (R) & \\
\hline \multirow[t]{2}{*}{$\beta$-catenin } & CTGACCAAACTGCTAAATGACG (F) & \multirow{2}{*}{208} \\
\hline & GATGGTGGGAAAGGTTGTGTAG (R) & \\
\hline \multirow[t]{2}{*}{ Actb } & CACCCGCGAGTACAACCTTC (F) & \multirow{2}{*}{207} \\
\hline & CCCATACCCACCATCACACC (R) & \\
\hline
\end{tabular}

mixture were as per the manufacturer instructions. The real-time PCR program was as follows: 35 cycles each of denaturation at $95^{\circ} \mathrm{C}$, annealing at $58-60^{\circ} \mathrm{C}$, and elongation at $72{ }^{\circ} \mathrm{C}$. The melting curves were $\mathrm{S}$-shaped, indicated the absence of nonspecific amplicons. The level of Actb mRNA expression was used to normalize differences in the levels among different transcripts.

\section{Statistical analysis}

All data are presented as the mean \pm standard deviation (SD). Statistical analyses were performed using the SPSS 18.0 software. Multiple comparisons were performed using one-way ANOVA. P $<0.05$ was considered statistically significant.

\section{Results}

Effect of NaIO3 on the morphological features, survival, and proliferation of RGCs

In preliminary experiments, we treated $\mathrm{L} 2.3$ cells with different concentrations of $\mathrm{NaIO}_{3}$ as follows: low $(0.5 \mu \mathrm{g} / \mathrm{ml})$, medium $(5 \mu \mathrm{g} / \mathrm{ml})$, and high $(50 \mu \mathrm{g} / \mathrm{ml})$ doses. Observations of the cells using phase-contrast microscopy did not detect obvious morphological changes at any concentration. Two days after $\mathrm{NaIO}_{3}$ treatment, the density of cells treated with the highest dose peaked and then decreased. Cells treated with low- and medium-doses grew to a higher density that peaked on day 3 and then decreased dramatically. There was no significant difference between the growth of the control and low-dose-treated cells (Fig. 1).

Apoptosis increased as a function of increase in $\mathrm{NaIO}_{3}$ concentration, and more than $50 \%$ of the cells were apoptotic at the highest concentration. The difference between the control and cells treated with the lowest dose was not significant, consistent with the results of the cell proliferation assay (Fig. 2). The ratio of Caspase-3 positive cells was significantly higher when treated with medium and high doses of $\mathrm{NaIO}_{3}$ for 1 and 3 days, while low doses of $\mathrm{NaIO}_{3}$ did not changed the ratio of Caspase-3 positive cells (Fig. 3). And the ratio of TUNEL-positive cells was increased in a dose depended manner when treated with $\mathrm{NaIO}_{3}$ in 1 to 3 days (Fig. 4).

The mitotic ratio was highest for all $\mathrm{NaIO}_{3}$ concentrations after day 1 and then decreased. The ratio was lowest on day 2 and rose on day 3 . These results were similar to those of 


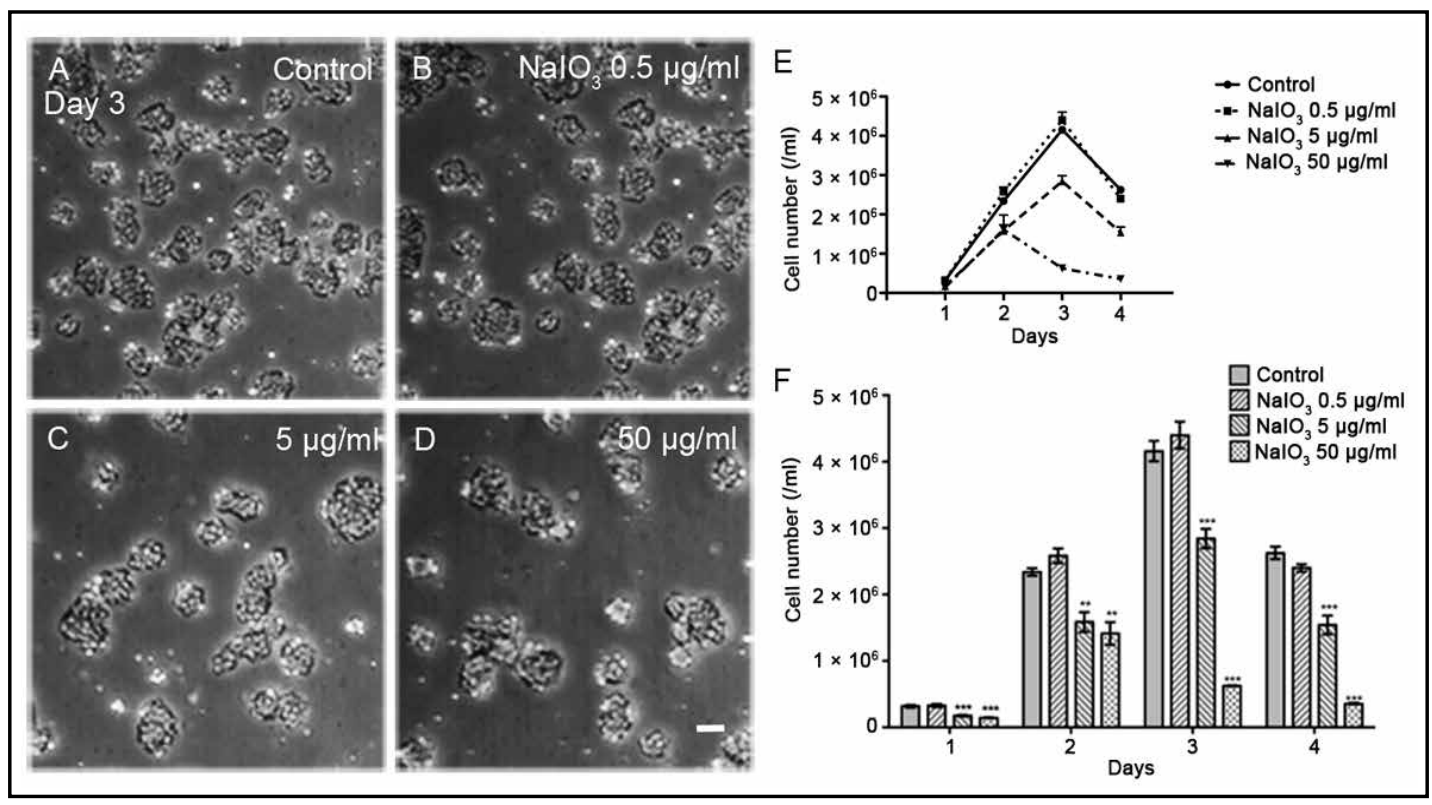

Fig. 1. Analysis of the proliferation of L2.3 cells in vitro. The number of cells in each well was determined at the indicated times. A-D Morphologic differences on day 3 among controls and cells treated with low (0.5 $\mu \mathrm{g} / \mathrm{ml})$, medium $(5 \mu \mathrm{g} / \mathrm{ml})$, or high doses $(50 \mu \mathrm{g} / \mathrm{ml})$ of $\mathrm{NaIO}_{3}$. E, F Growth rates of $\mathrm{L} 2.3$ cells in the presence or absence of $\mathrm{NaIO}_{3}$. Data from at least three independent experiments are represented as the mean \pm (SD). ${ }^{*} P<0.05,{ }^{* *} P<0.01,{ }^{* * *} P<0.001$, compared with time-matched controls. Scale bars $=40 \mu \mathrm{m}$.

Fig. 2. FACS analysis of apoptosis in L2.3 cells incubated with $\mathrm{NaIO}_{3}$. Apoptotic cells were identified by the increase in the fluorescence intensity of FITClabeled Annexin V. A FACS data. B Time course of apoptosis. Data from at least three independent experiments represent the mean \pm SD. $* P<0.05,{ }^{* *} P<0.01$, ${ }^{* * *} P<0.001$, versus untreated cells.

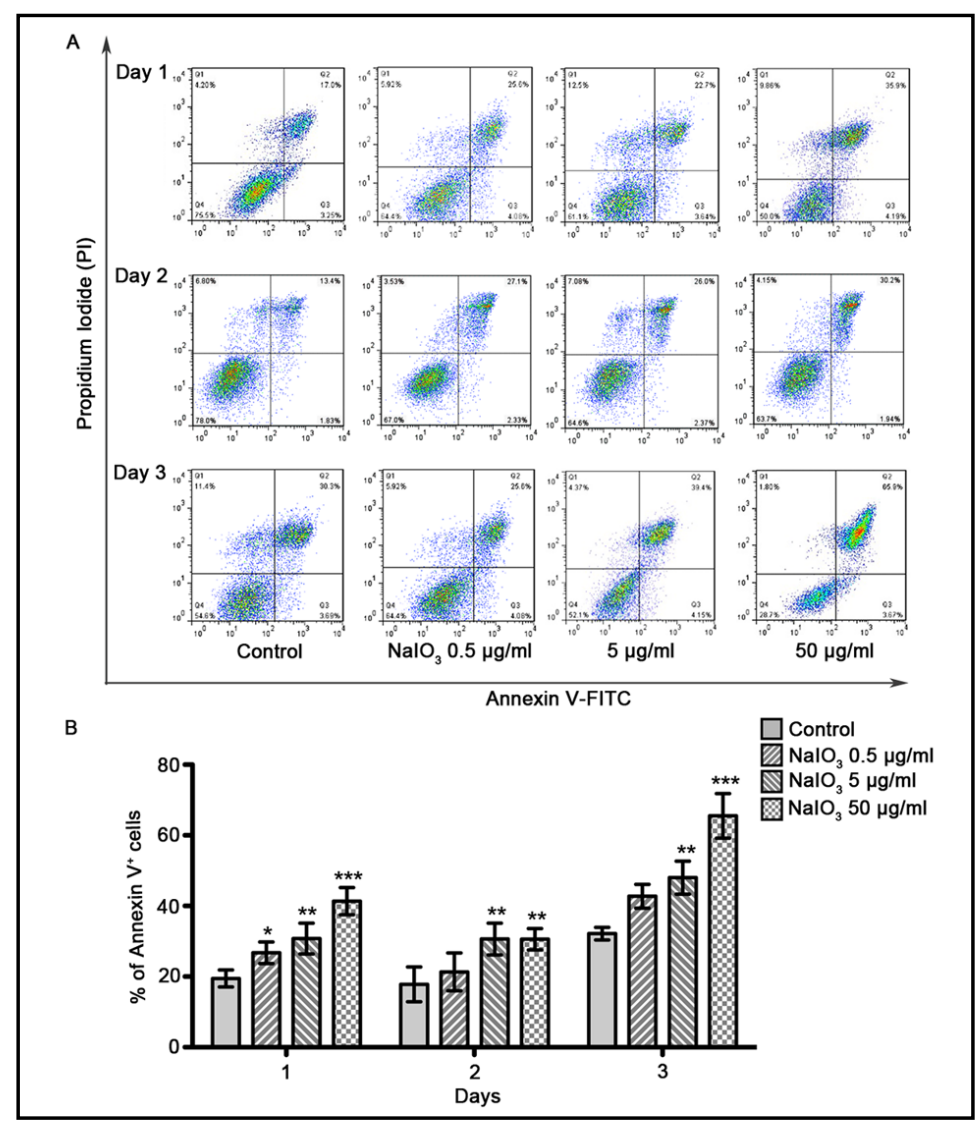

the control cells and low-dose cells. The mitotic ratio of cells treated with the medium dose was lower than that of the controls over the 3 days of the experiment. The mitotic ratio of 
Fig. 3. Effect of $\mathrm{NaIO}_{3}$ treatment for 1-3 days on the ratio of Caspase3-positive cells among the L2.3 cells. A-C Representative images of L2.3 cells double-stained with Caspase-3 (red) and DAPI (blue). D Statistical analysis of the ratio of Caspase3-positive cells. Data from at least three independent experiments are expressed as the mean \pm SD. ${ }^{*} P<0.05,{ }^{* *} P<0.01,{ }^{* * *} P<0.001$, versus untreated cells. Scale bars $=$ $40 \mu \mathrm{m}$.

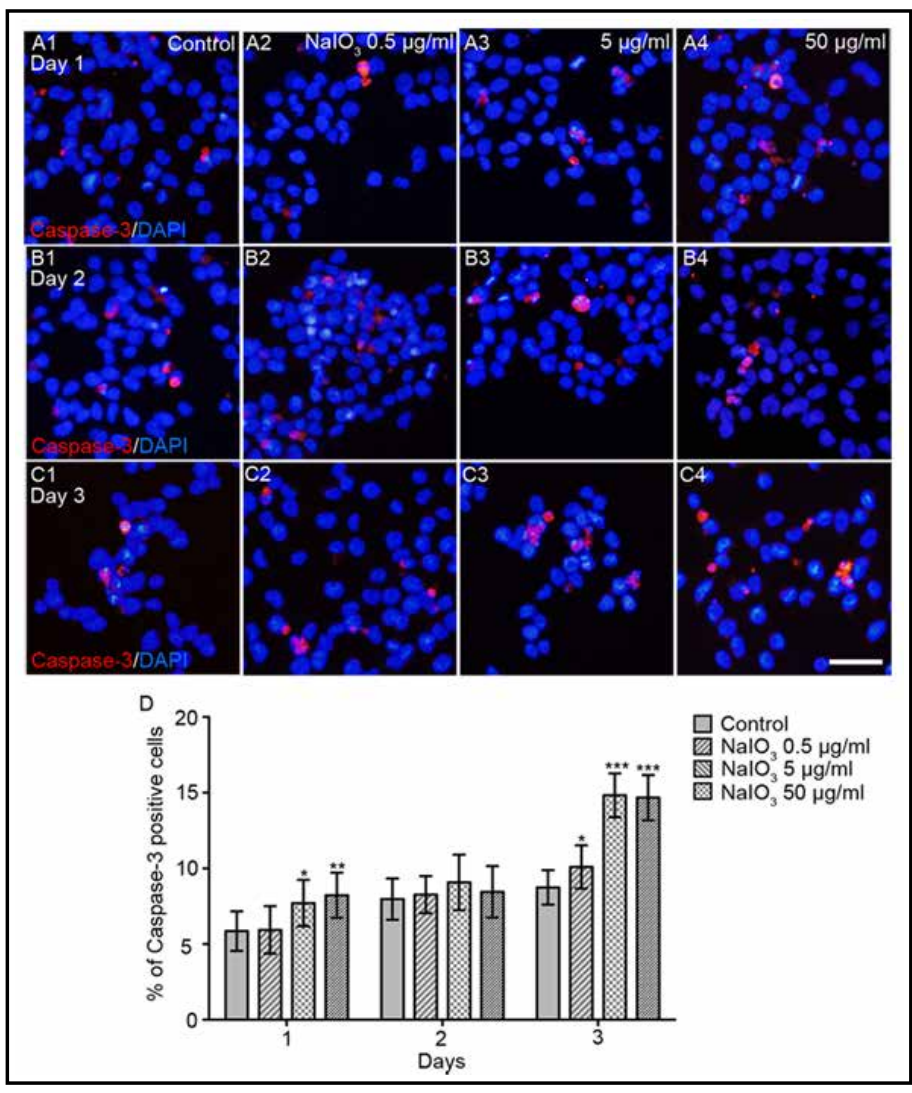

Fig. 4. Effect of $\mathrm{NaIO}_{3}$ treatment for 1-3 days on the ratio of TUNEL-positive cells among the L2.3 cells A-C Representative images of L2.3 cells double-stained with TUNEL (green) and DAPI (blue). D Statistical analysis of the ratio of TUNEL -positive cells. Data from at least three independent experiments are expressed as the mean \pm SD. $* P<0.05$, ${ }^{* *} P<0.01,{ }^{* * *} P<0.001$, versus untreated cells. Scale bars $=40 \mu \mathrm{m}$.

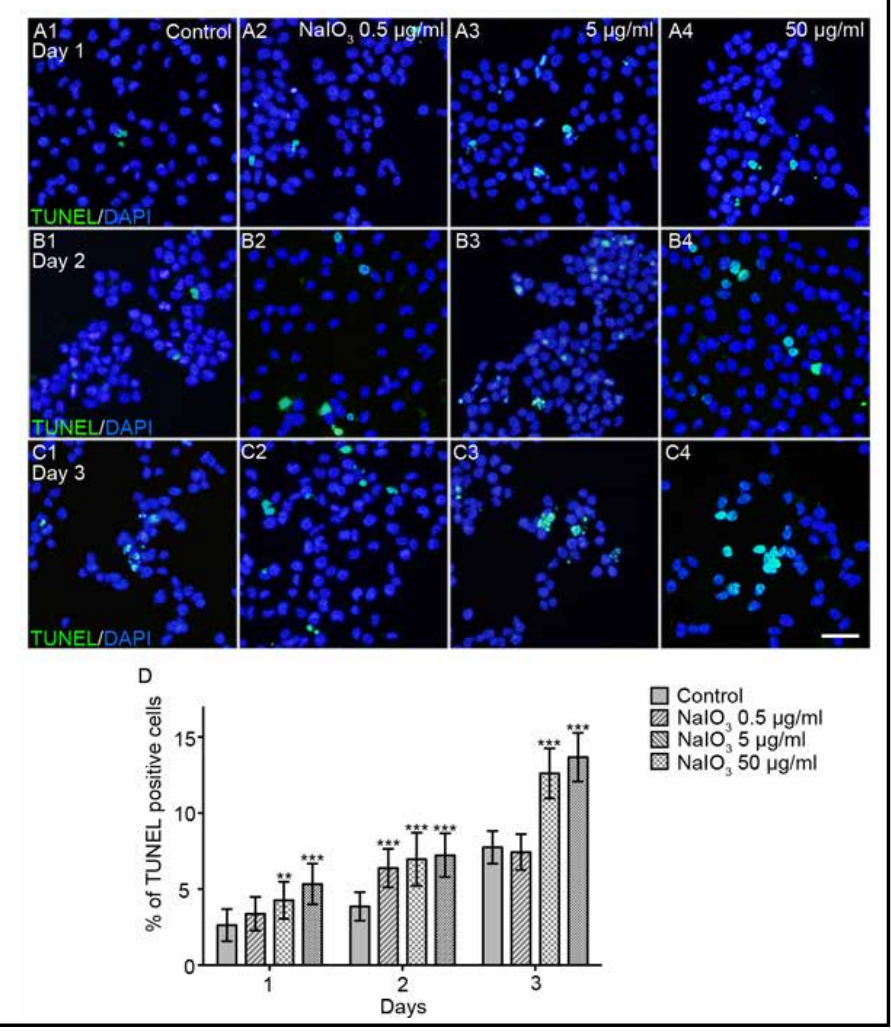

cells treated with the highest dose was the lowest on day 1 and increased slightly thereafter (Fig. 5). 
Fig. 5. Cell cycle analysis of L2.3 cells treated with $\mathrm{NaIO}_{3}$ for 3 days. A Representative cell-cycle data. B Statistical analysis. All data are expressed as the mean \pm SD of at least three separate experiments. ${ }^{*} P<0.05,{ }^{* *} P<0.01$, $* * * P<0.001$, versus untreated cells.

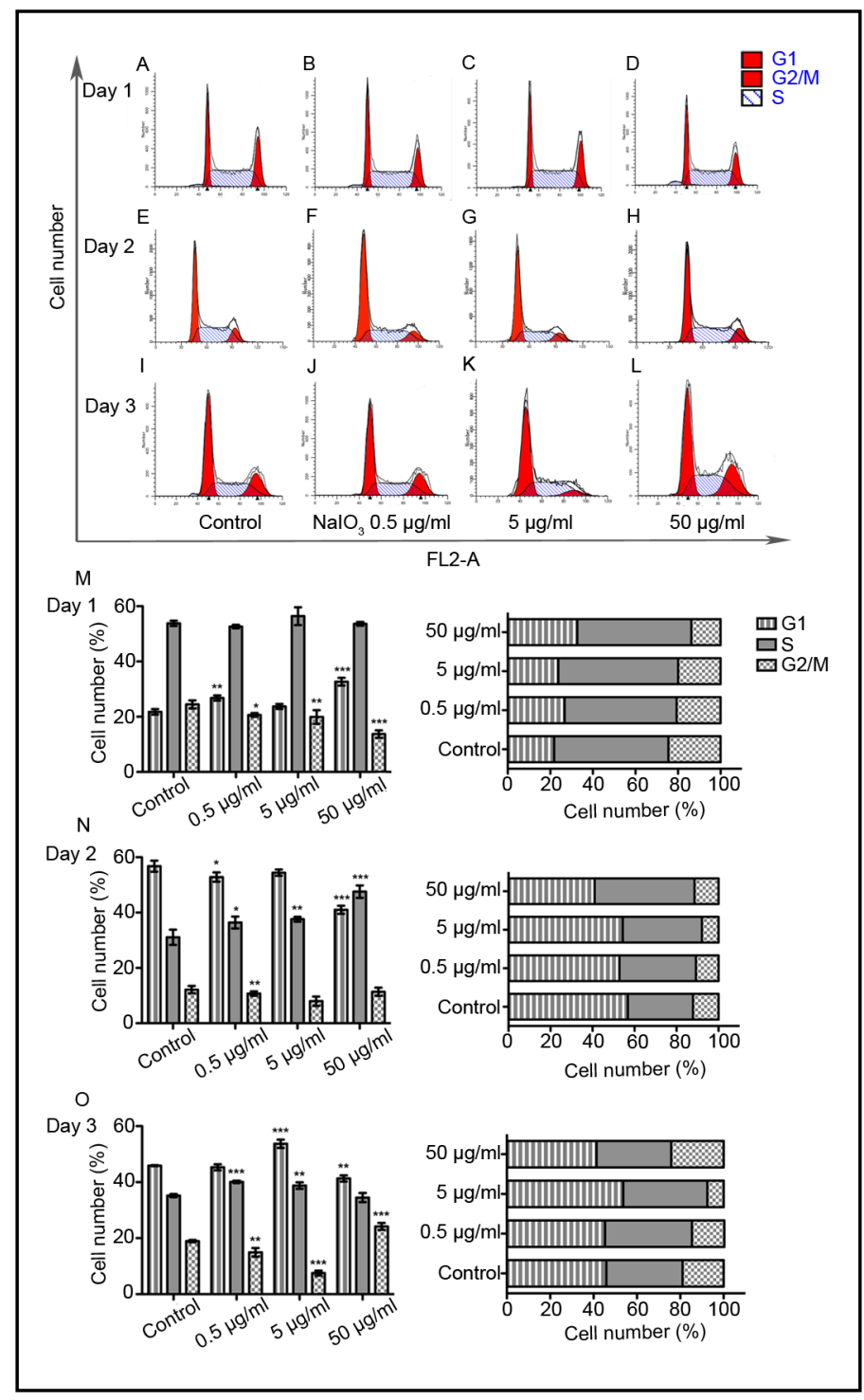

To investigate the effect of $\mathrm{NaIO}_{3}$ on the proliferation of L2.3 cells, we measured the incorporation of BrdU. The ratio of BrdU-positive cells peaked on day 2. There was no significant difference in BrdU incorporation ratio between treated and control groups on day 1 . On days 2 and 3, the BrdU incorporation ratio of RGCs treated with medium and high doses of $\mathrm{NaIO}_{3}$ was lower than those of control cells and those treated with low doses of $\mathrm{NaIO}_{3}$. However, there was no significant difference in the ratio between the low-dose $\mathrm{NaIO}_{3}$ group and controls (Fig. 6).

\section{NaIO3-induced inhibition of the Wnt/ $\beta$-catenin signaling cascade}

AXIN2 is a direct target of Wnt, and Axin2 expression is used to evaluate Wnt/ $\beta$-catenin signaling [36]. In contrast, Wnt signaling inhibits GSK-3 $\beta$ activity [37]. To evaluate the role of the Wnt/ $\beta$-catenin signaling pathway in $\mathrm{NaIO}_{3}$-treated $\mathrm{L} 2.3$ cells, we performed real-time PCR assays to evaluate the expression levels of Axin2, $\beta$-catenin and Gsk-3 $\beta$. Treatment with $\mathrm{NaIO}_{3}$ inhibited the expression of Axin2 and $\beta$-catenin mRNAs, whereas the expression of Gsk-3 $\beta$ (Fig. 7A-C) significantly increased.

To confirm the role of the Wnt/ $\beta$-catenin pathway in the apoptosis and proliferation of L2.3 cells exposed to $\mathrm{NaIO}_{3}$, we treated the cultures with the Wnt agonist CHIR99021. The decrease in density of RGCs induced by medium and high doses of $\mathrm{NaIO}_{3}$ was blocked 

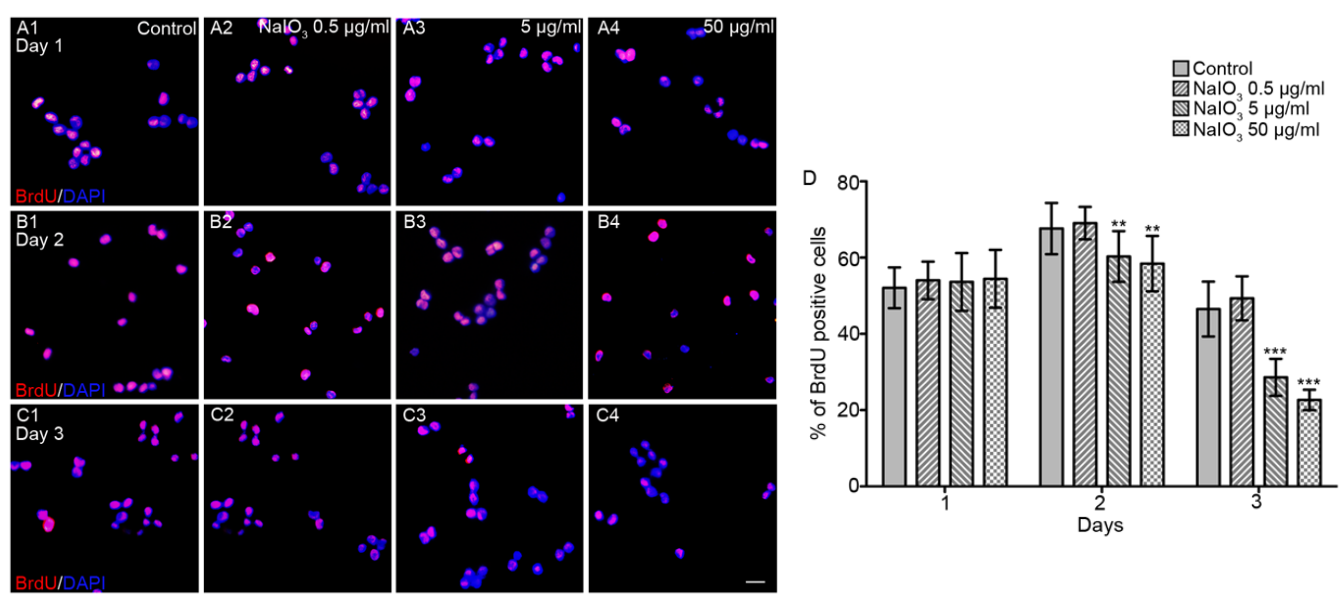

Fig. 6. $\mathrm{NaIO}_{3}$ treatment inhibited the proliferation of L2.3 cells. A-C Representative images of L2.3 cells double-stained with BrdU (red) and DAPI (blue). D Statistical analysis of BrdU expression. Data from at least three independent experiments are expressed as the mean \pm SD. $* P<0.05,{ }^{* *} P<0.01,{ }^{* * *} P<0.001$, versus untreated cells. Scale bars $=20 \mu \mathrm{m}$.

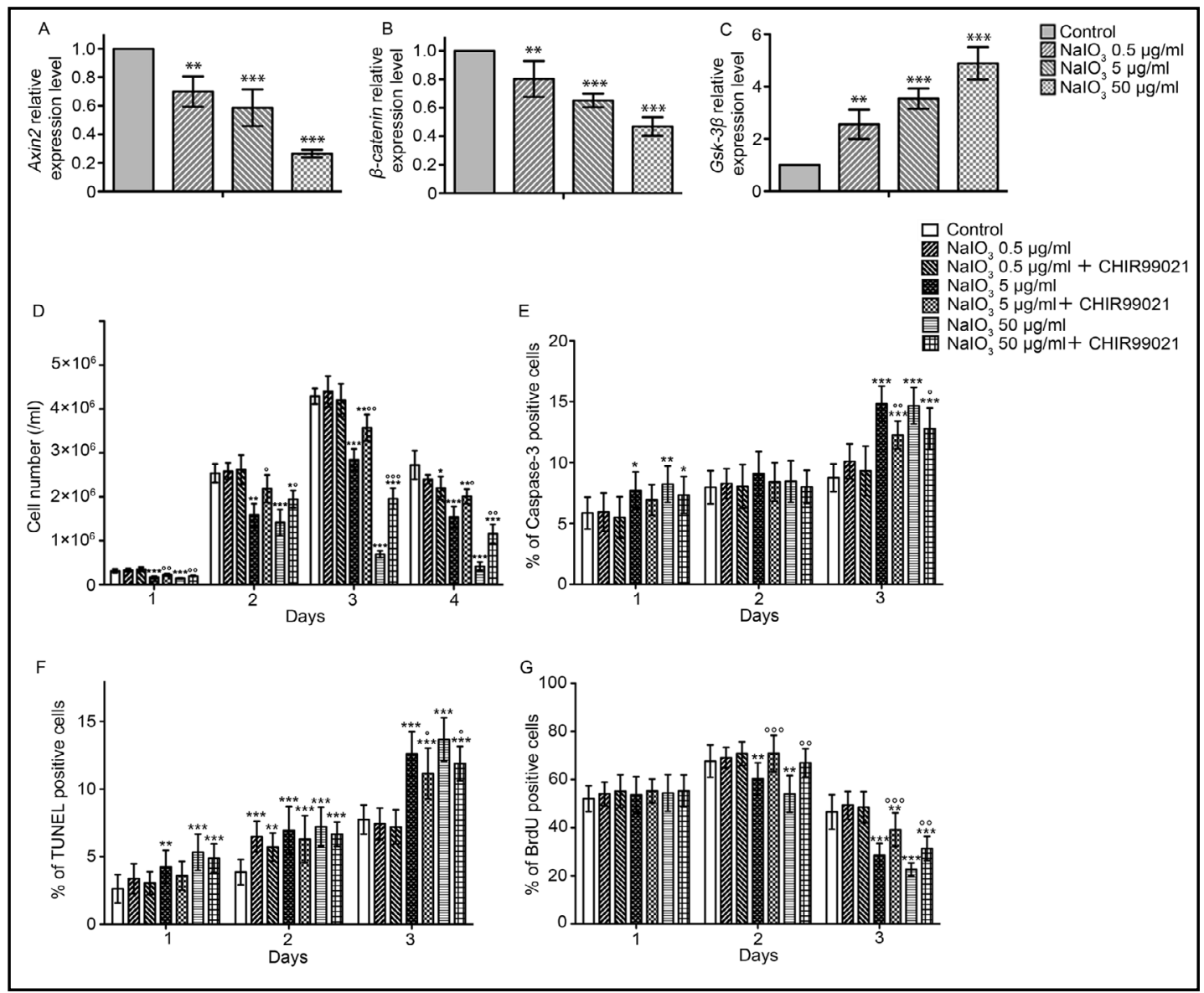

Fig. 7. Effect of $\mathrm{NaIO}_{3}$ on the expression levels of mRNAs encoding components of the Wnt/ $\beta$-catenin signaling pathway. A-C Real-time PCR analysis of the expression of Axin2, $\beta$-catenin, and Gsk-3 $\beta$. D, E, F, G Growth rates, Caspase-3 expression, TUNEL activity, and BrdU incorporation of L2.3 cells in the presence or absence of $\mathrm{NaIO}_{3}$ and $\mathrm{CHIR} 99021$. The mean $\pm \mathrm{SD}$ of three individual determinations are presented for each transcript. ${ }^{*} P<0.05,{ }^{* *} P<0.01,{ }^{* * *} P<0.001$, versus control, ${ }^{\circ} P<0.05,{ }^{\circ} P<0.01,{ }^{\circ}{ }^{\circ} P<0.001$, versus the corresponding dose of $\mathrm{NaIO}_{3}$. 
Fig. 8. $\mathrm{NaIO}_{3}$ treatment decreased the number and synaptic lengths of Tuj1-positive cells derived from L2.3 cells. A-D Representative images of Tuj1 expression. E, F Comparison of synaptic lengths of Tuj1-positive cells between cells treated with the high dose $(50 \mu \mathrm{g} / \mathrm{ml})$ and the controls. G Percentage of Tuj1positive cells as a function of $\mathrm{NaIO}_{3}$ concentration. Data from at least three independent experiments are expressed as the mean \pm SD. ${ }^{*} P<0.05,{ }^{* *} P<0.01$, ${ }^{* * *} P<0.001$, versus untreated cells. Scale bars $=20 \mu \mathrm{m}$.

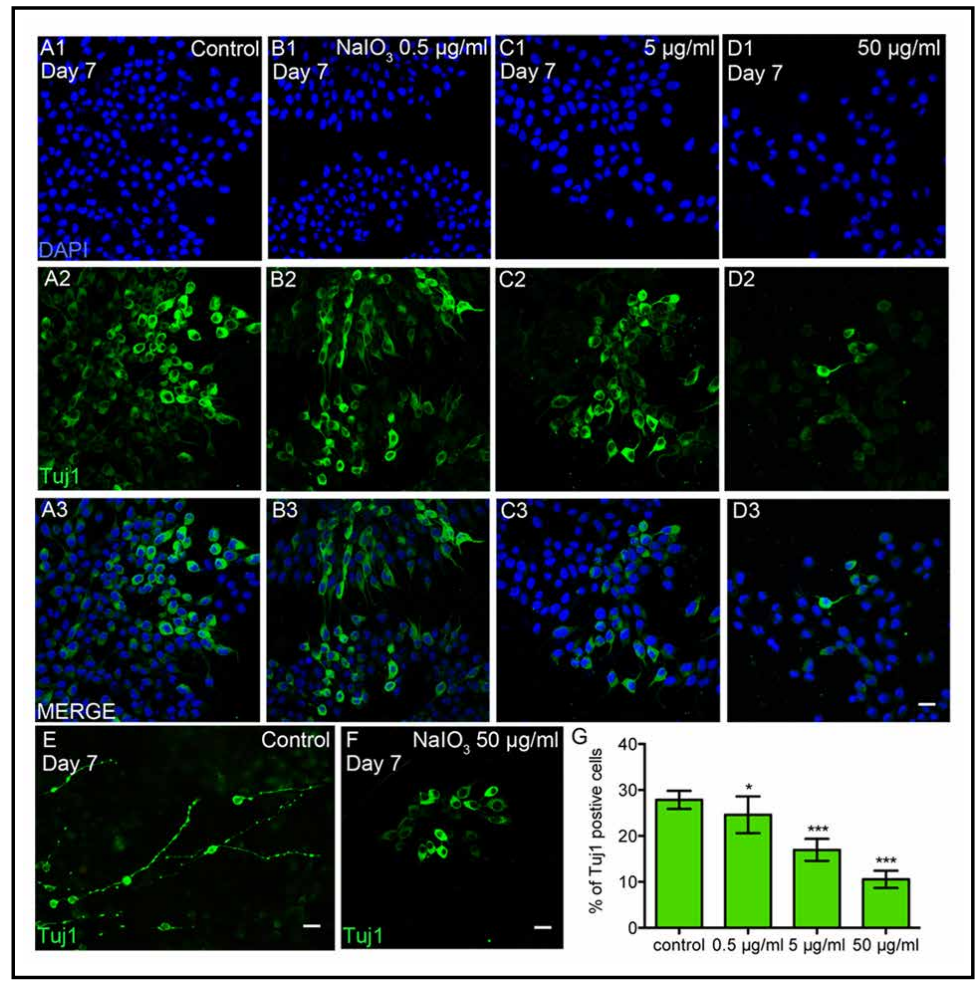

Fig. 9. Analysis of GFAP expression on day 7 after treatment with $\mathrm{NaIO}_{3}$. A-E Representative confocal images of GFAP immunofluorescence. Cell nuclei were labeled with DAPI. Scale bars $=20$ $\mu \mathrm{m}$.

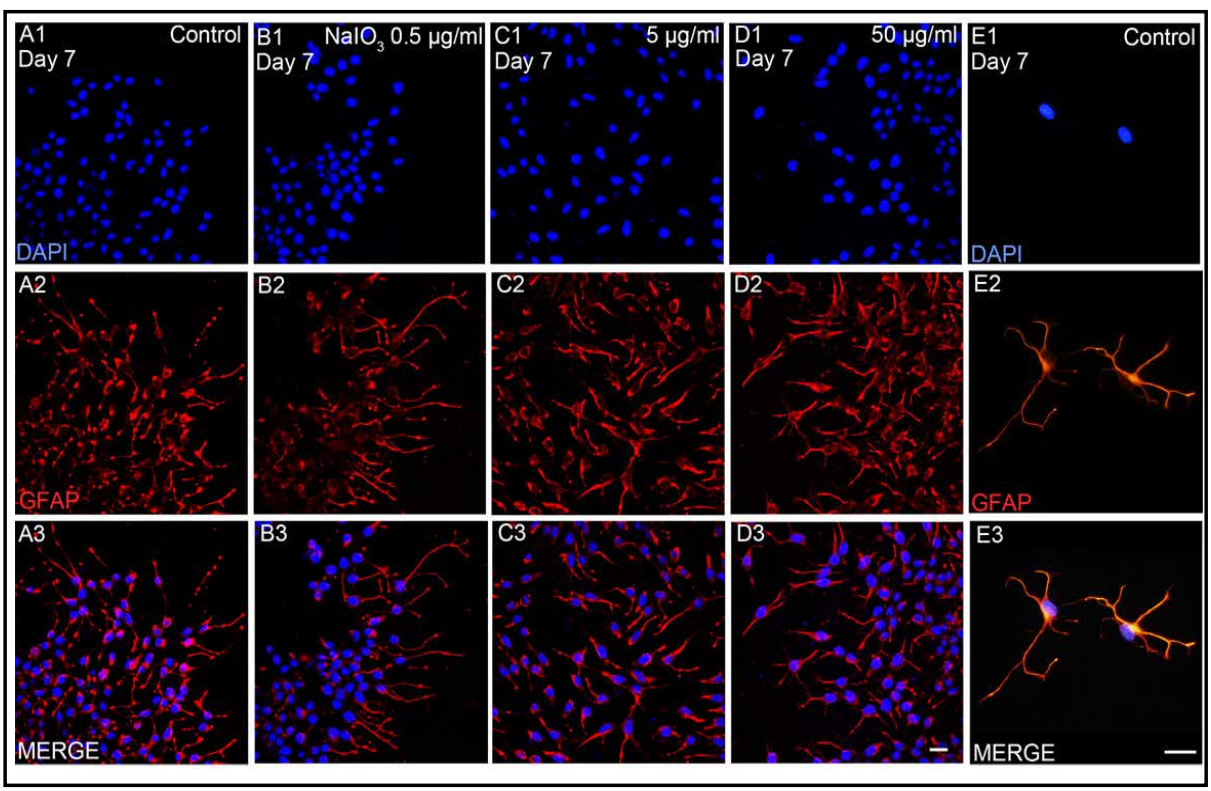

by CHIR99021 (Fig. 7D). Moreover, CHIR99021 antagonized the increase in the number of Caspase-3 positive (Fig. 7E), TUNEL positive cells (Fig. 7F), and the reduction in the number of BrdU-positive cells (Fig. 7G) incorporation ratio in the presence of medium and high doses of $\mathrm{NaIO}_{3}$ for 1-3 days.

\section{Effect of $\mathrm{NaIO}_{3}$ on the potential of L2.3 cells to differentiate}

Tuj1 and GFAP are markers for newly generated neurons and astrocytes, respectively [38]. In the presence of increasing concentrations of $\mathrm{NaIO}_{3}$, the ratio of Tuj1-positive cells decreased (Fig. 8A-D) and the expression differences were statistically significant according 
Fig. 10. FACS analysis of Tuj1 and GFAP expression on day 7 after induction of differentiation. A-D Representative results of Tuj1-positive cells. E Statistical analysis of Tuj1 expression. F-I Representative results of the percentage of GFAP-positive cells. J Statistical analysis of GFAP expression. The data represent the mean \pm SD of three independent determinations. ${ }^{*} P<0.05,{ }^{* *} P<0.01,{ }^{* * *} P<0.001$, versus untreated cells.
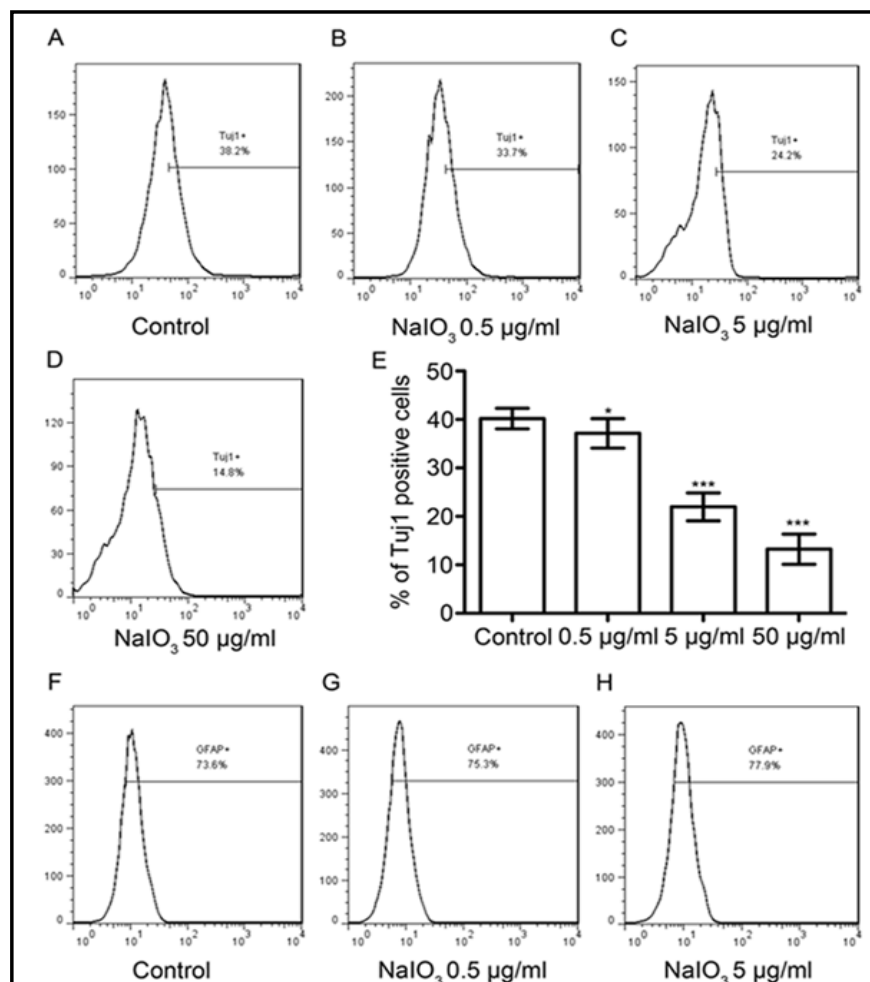

G $\quad H$

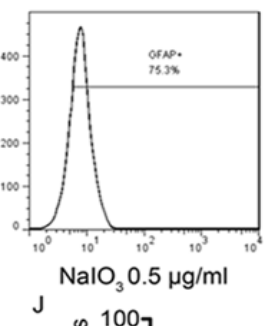
$\mathrm{H}$
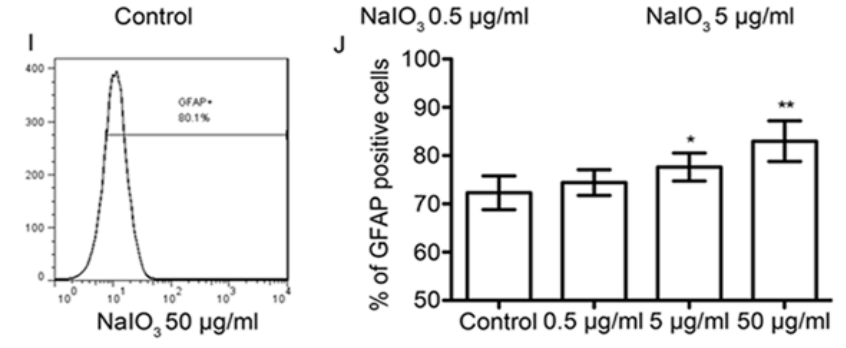

Fig. 11. Immunocytochemical analysis of Tuj1/BrdU and GFAP/ BrdU-positive cells derived from L2.3 cells on day 7. A Representative images of Tuj1/BrdU expression. B Representative images of GFAP/BrdU expression. C Percentage of Tuj1/BrdU double stained cells in BrdU-positive cells as a function of $\mathrm{NaIO}_{3}$ concentration. D Percentage of GFAP/BrdU double stained cells in BrdU-positive cells. Data from at least three independent experiments are expressed as the mean $\pm \mathrm{SD} .{ }^{*} P<0.05$, ${ }^{* *} P<0.01,{ }^{* * *} P<0.001$, versus untreated cells. Scale bars $=20 \mu \mathrm{m}$.
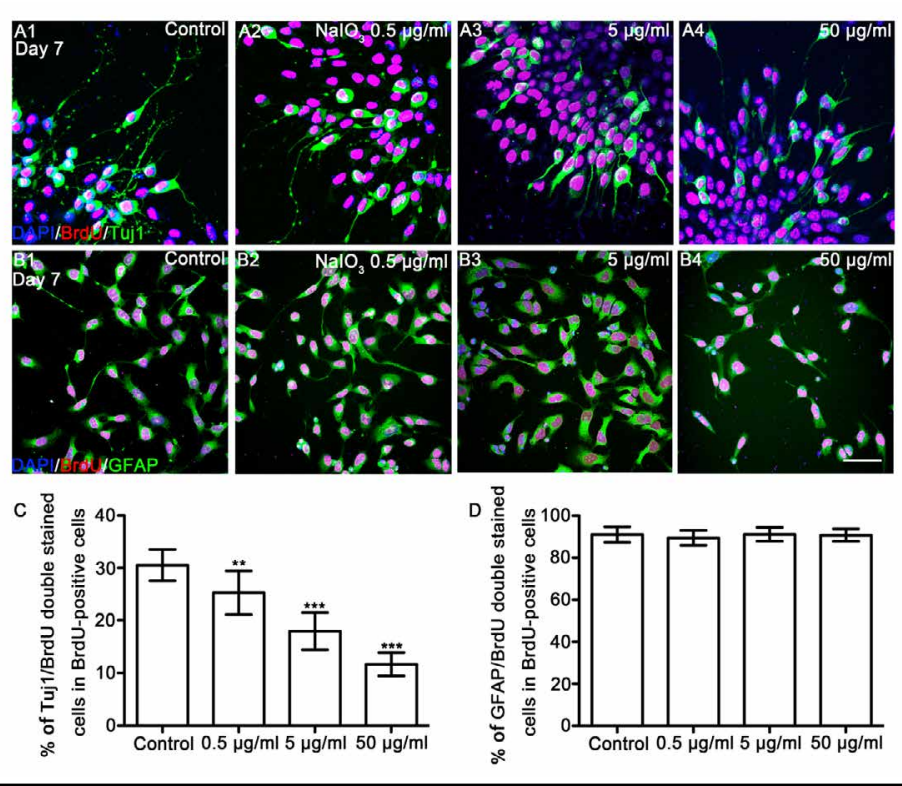

to the results of the positive cell counting assays (Fig. 8G). We also found that synaptic length of Tuj1-positive cells decreased in the presence of higher concentrations of $\mathrm{NaIO}_{3}$ (Fig. 8E, 

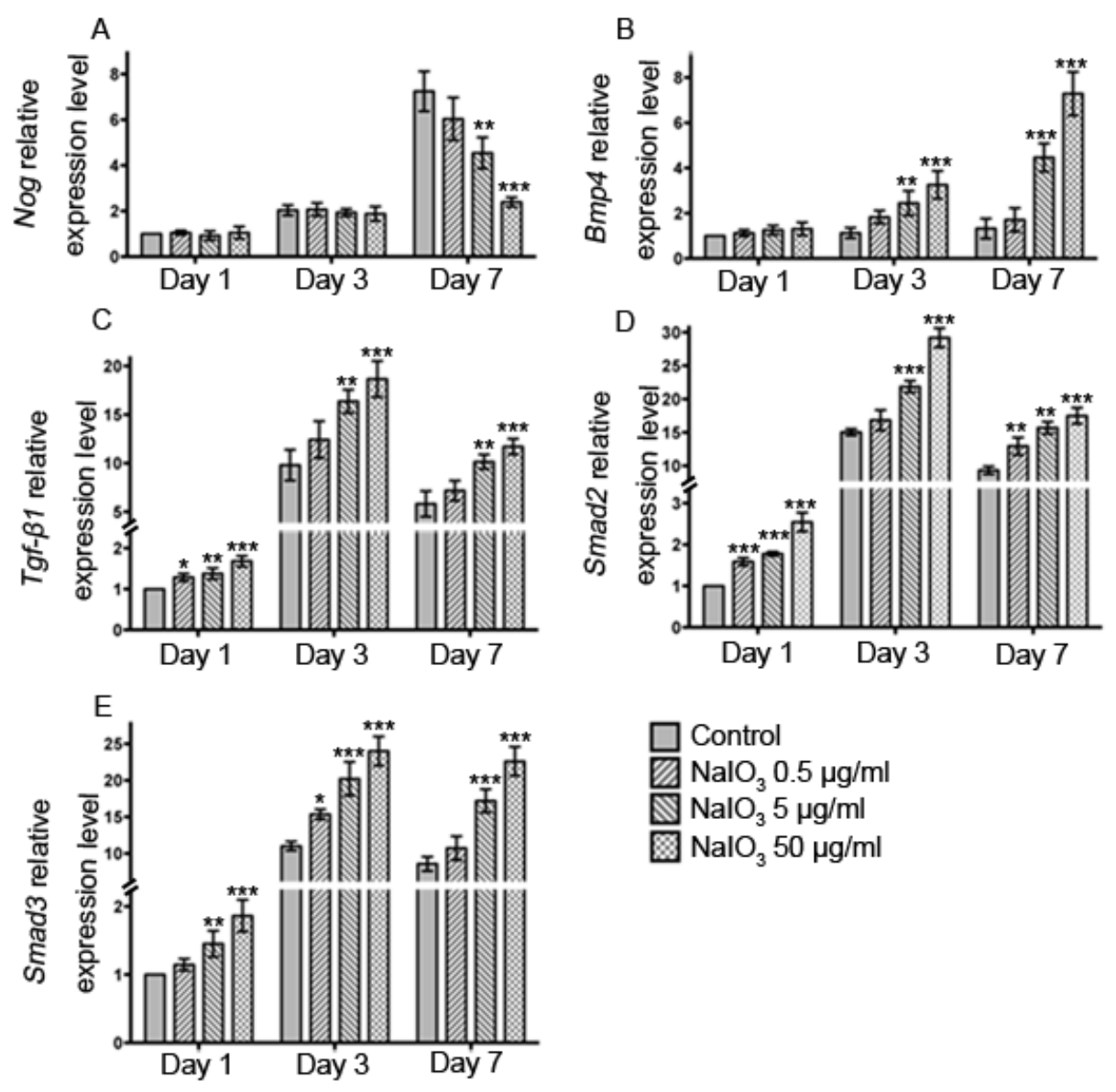

Fig. 12. The $\mathrm{NaIO}_{3}$-induced decrease in Tuj1-positive cells and increase in GFAP-positive cells derived from L2.3 cells correlated with the expression levels of components of the Noggin and TGF- $\beta 1 /$ SMAD2/3 signaling pathways. A, B Quantitation of the expression of $\mathrm{Nog}$ and Bmp4. C-E Quantification of the relative levels of transcription of genes encoding components of the TGF- $\beta 1 / S M A D 2 / 3$ signaling pathway. All data are expressed as the mean \pm SD from at least three independent experiments. ${ }^{*} P<0.05,{ }^{* *} P<0.01,{ }^{* * *} P<0.001$, versus untreated cells.

F). Moreover, the results of the FACS analysis support the conclusion that $\mathrm{NaIO}_{3}$ inhibited neuronal differentiation, which is consistent with the immunocytochemical results (Fig. 10A-E).

We next determined the expression of GFAP and found no significant difference between the cells treated with different concentrations of $\mathrm{NaIO}_{3}$ and the controls (Fig. 9). When we determined the levels of GFAP expression using FACS, the results were the opposite of those for Tuj1 expression described above and indicated that more L2.3 cells differentiated into astrocytes in the presence of increasing concentrations of $\mathrm{NaIO}_{3}$ (Fig. 10F-J).

To exclude the influence of cell death, we analyzed the differentiation of RGCs with birthdating by adding BrdU to the differentiation medium on day 0 . On day 7 , the ratio of Tuj1/BrdU double-stained cells in BrdU-positive cells decreased as a function of $\mathrm{NaIO}_{3}$ concentration, while there was no significant difference in the ratio of GFAP/BrdU doublestained cells among the BrdU-positive cells treated with different doses of $\mathrm{NaIO}_{3}$. These results are consistent with those acquired using immunocytochemical analyses (Fig. 11). 


\section{$\mathrm{NaIO}_{3}$-induced regulation of Nog (Noggin) and Tgf- $\beta 1 / \mathrm{Smad} 2 / 3$ expression}

To further analyze the effect of $\mathrm{NaIO}_{3}$ on the differentiation potential of $\mathrm{L} 2.3$ cells, we analyzed the levels of mRNAs encoding Noggin, BMP4, TGF- $\beta 1$, SMAD2, and SMAD3, which are critical components of the Noggin and TGF- $\beta 1 /$ SMAD2/3 signaling pathways. $\mathrm{NaIO}_{3}$ treatment at all concentrations did not alter the level of $N o g$ expression on the first and third days after differentiation; however, on the seventh day, Nog expression was markedly downregulated in cells treated with $\mathrm{NaIO}_{3}$, compared with the expression in the control (Fig. 12A). The expression level of Bmp4 did not differ significantly among treated cells and controls on day 1 . In contrast to the findings for Nog expression, Bmp4 expression began to increase from day 3 and became significantly higher by day 7 (Fig. 12B). The expression levels of Tgf- $\beta 1, S m a d 2$, and Smad3 in treated and untreated cultures started to increase on day 1 , reached a peak on the day 3 , and decreased slightly on day 7 (Fig. 12C-E).

\section{Discussion}

Genetic and age-related diseases caused by the degeneration or dysfunction of the RPE represent the most common causes of visual loss and blindness [39, 40]. For over 60 years, researchers focusing on preventing and treating visual impairment have employed the animal model of retinal injury induced by systemic injection with $\mathrm{NaIO}_{3}$ [41] because it faithfully reflects the pathogenesis of acute retinal damage. Thus, intravenous injection of $\mathrm{NaIO}_{3}$ leads to selective degeneration and atrophy of the RPE and subsequent injury to photoreceptors. However, the effect of $\mathrm{NaIO}_{3}$ on endogenous RSCs is still unclear. Therefore, the goal of the present study was to take advantage of the $\mathrm{NaIO}_{3}$ model system to better understand the potential of RGCs to proliferate and differentiate, with the hope of stimulating more research on degenerative diseases of the eye.

Here, we found that $\mathrm{NaIO}_{3}$ caused significant damage to L2.3 cells in vitro. Thus, cell density and BrdU incorporation decreased as a function of increase in the $\mathrm{NaIO}_{3}$ concentration with a concomitant increase in apoptosis. Although cell cycle analysis indicated that the mitotic ratio of cells treated with the highest dose of $\mathrm{NaIO}_{3}$ was the highest on days 2 and 3 after treatment, a greater number of cells underwent apoptosis, causing an overall marked decrease in cell density.

$\mathrm{NaIO}_{3}$ exposure usually resulted in the degeneration of mouse RPE cells selectively, followed by the apoptosis of photoreceptors in the retina. It demonstrated that the necrosis of RPE cells in the mice was evoked as early as 6 hours post $\mathrm{NaIO}_{3}$ treatment, while apoptosis of the photoreceptors were observed at 24 hours, peaked on day 3 and completed on days $7[14,42]$. Our experiment showed that $\mathrm{NaIO}_{3}$ also induced the apoptosis of L2.3 cells in a dose-dependent manner.

$\mathrm{NaIO}_{3}$ inhibited the proliferation of L2.3 cells, which prompted us to investigate the underlying mechanism. The Wnt/ $\beta$-catenin signal transduction pathway plays an important role in the proliferation capacity of L2.3 cells. L'Episcopo et al. found that oxidative injury to RGCs leads to downregulation of the expression of $\beta$-catenin and the overexpression of GSK$3 \beta$, whereas inhibiting Wnt/ $\beta$-catenin signaling using small interfering RNA to inhibit GSK$3 \beta$ expression or antagonize GSK-3 $\beta$ activity reverses neurogenic impairment $[37,43]$. These findings indicate that the $\mathrm{Wnt} / \beta$-catenin/GSK-3 $\beta$ pathway acts to regulate the proliferation of injured RGCs. Consistent with these results, we found here that $\mathrm{NaIO}_{3}$ downregulated the

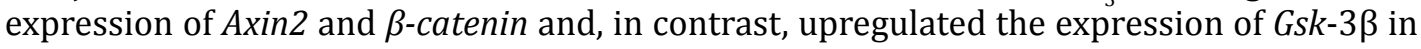
concert with the decrease in the proliferation of L2.3 cells. Further, a Wnt agonist efficiently reversed the inhibitory effects of $\mathrm{NaIO}_{3}$ on the proliferation of RGCs. These findings indicate that $\mathrm{NaIO}_{3}$ impaired the ability of RGCs to proliferate through inhibition of the Wnt/ $\beta$ catenin pathway.

NSCs differentiate into astrocytes, oligodendrocytes, and neurons [38, 44]. Müller glial cells are considered RGCs in the retina, and their overgrowth may lead to the formation of glial scars in the retina, potentially followed by loss of vision. Therefore, we investigated 
whether $\mathrm{NaIO}_{3}$ treatment influenced the direction of RGCs differentiation toward astrocytes or neurons. When we compared the ratio of Tuj1- and GFAP-positive cells in cultures treated with different concentrations of $\mathrm{NaIO}_{3}$, we found that the higher concentrations of $\mathrm{NaIO}_{3}$ promoted L2.3 cells to differentiate into astrocytes while preventing them from becoming neurons. Increased numbers of astrocytes may induce the generation of a glial scar and adversely affect wound healing.

Several signaling pathways regulate the differentiation of L2.3 cells. BMP4 signaling directs radial glia-like cells to differentiate into astroglia, whereas Noggin antagonizes BMP4 activity and promotes the differentiation of radial glia-like cells into neurons in vivo [29]. The balance between Noggin and BMP4 signaling regulates the differentiation pathway of radial glia. Here, we found that downregulation of Noggin and upregulation of BMP4 occurred almost simultaneously when cells were treated with $\mathrm{NaIO}_{3}$. This result is consistent with the inhibition of neuronal differentiation.

TGF- $\beta 1$ is a pleiotropic cytokine that orchestrates multiple physiological events in the nervous system [45]. The canonical TGF- $\beta 1$ signaling pathway involves the transcription factors SMAD2/3 and SMAD4. TGF- $\beta 1$ induces the receptor-mediated phosphorylation of SMAD2/3, which then bind to SMAD4 to promote differentiation to astrocytes in vitro and in vivo [46]. Moreover, TGF- $\beta 1$ is one of the most important astrocytic factors [32]. Li et al. reported that RGCs differentiate into astrocytes within 6 days in vitro culture in DMEM/F12containing N2B27 differentiation medium [35]. Here, we found that the expression of Tgf- $\beta 1$ and $\mathrm{Smad} 2 / 3$ was significantly elevated on day 3 after $\mathrm{NaIO}_{3}$ exposure and dropped slightly on day 7 , suggesting that differentiation into astrocytes peaked on day 3 .

In summary, to our knowledge, this study is the first to show that $\mathrm{NaIO}_{3}$ exerts remarkable effects on the apoptosis, proliferation and the differentiation potential of RGCs in vitro. Moreover, our results suggest that the Wnt/ $\beta$-catenin, Noggin, and TGF- $\beta 1 /$ SMAD2 $/ 3$ signaling pathways mediate these events. Although further studies are necessary, our findings provide a theoretical basis for innovation and indicate that inhibiting the differentiation of RSCs into astrocytes may offer a new therapeutic strategy for preventing impairment of vision caused by astrocyte-induced retinal scar formation.

\section{Acknowledgements}

This study was supported by National Basic Research Program of China (no. 2013CB967002) and National Nature Science Foundation of China (no. 8113001, 31271051). The authors thank Dr. Hedong Li of Sichuan University for providing L2.3 cells.

\section{Disclosure Statement}

None of the authors have a conflict of interest to declare.

\section{References}

1 Klein R, Peto T, Bird A, Vannewkirk MR: The epidemiology of age-related macular degeneration. Am J Ophthalmol 2004;137:486-495.

2 Schraermeyer U, Heimann K: Current understanding on the role of retinal pigment epithelium and its pigmentation. Pigment Cell Res 1999;12:219-236.

3 Tao Z, Dai J, He J, Li C, Li Y, Yin ZQ: The influence of NaIO(3)-induced retinal degeneration on intraretinal layer and the changes of expression profile/morphology of DA-ACs and mRGCS. Mol Neurobiol 2013;47:241-260. 


\section{Cellular Physiology $\quad$ Cell Physiol Biochem 2014;34:1109-1124 and Biochemistry \\ Chen/Li/Xu/Yin: $\mathrm{NaIO}_{3}$ Influences the Stemness of Radial Glial Cells}

4 Schmeer CW, Wohl SG, Isenmann S: Cell-replacement therapy and neural repair in the retina. Cell Tissue Res 2012;349:363-374.

5 Lamba D, Karl M, Reh T: Neural regeneration and cell replacement: a view from the eye. Cell Stem Cell 2008;2:538-549.

6 Das AV, Mallya KB, Zhao X, Ahmad F, Bhattacharya S, Thoreson WB, Hegde GV, Ahmad I: Neural stem cell properties of Muller glia in the mammalian retina: regulation by Notch and Wnt signaling. Dev Biol 2006;299:283-302.

-7 Ooto S, Akagi T, Kageyama R, Akita J, Mandai M, Honda Y, Takahashi M: Potential for neural regeneration after neurotoxic injury in the adult mammalian retina. Proc Nat Acad Sci USA 2004;101:13654-13659. Wan J, Zheng H, Chen ZL, Xiao HL, Shen ZJ, Zhou GM: Preferential regeneration of photoreceptor from Muller glia after retinal degeneration in adult rat. Vision Res 2008;48:223-234.

9 Dahl D, Crosby CJ, Sethi JS, Bignami A: Glial fibrillary acidic (GFA) protein in vertebrates: immunofluorescence and immunoblotting study with monoclonal and polyclonal antibodies. J Comp Neurol 1985;239:75-88.

10 Pixley SK, de Vellis J: Transition between immature radial glia and mature astrocytes studied with a monoclonal antibody to vimentin. Brain Res 1984;317:201-209.

11 Shaw G, Weber K: The structure and development of the rat retina: an immunofluorescence microscopical study using antibodies specific for intermediate filament proteins. Eur J Cell Biol 1983;30:219-232.

12 Raymond PA, Barthel LK, Bernardos RL, Perkowski JJ: Molecular characterization of retinal stem cells and their niches in adult zebrafish. BMC Dev Biol 2006;6:36.

13 Karl MO: The potential of stem cell research for the treatment of neuronal damage in glaucoma. Cell Tissue Res 2013;353:311-325.

-14 Kiuchi K, Yoshizawa K, Shikata N, Moriguchi K, Tsubura A: Morphologic characteristics of retinal degeneration induced by sodium iodate in mice. Current Eye Res 2002;25:373-379.

15 Seitz R, Ohlmann A, Tamm ER: The role of Müller glia and microglia in glaucoma. Cell Tissue Res 2013;353:339-345.

16 Egensperger R, Maslim J, Bisti S, Hollaneder H, Stone J: Fate of DNA from retinal cells dying during development: Uptake by microglia and macroglia (Müller cells). Brain Res Dev Brain Res 1996;97:1-8.

17 Bringmann A, Iandiev I, Pannicke T, Wurm A, Hollborn M, Wiedemann P, Osborne NN, Reichenbach A: Cellular signaling and factors involved in Muller cell gliosis: Neuroprotective and detrimental effects. Prog Retin Eye Res 2009;28:423-451.

18 Carter-Dawson L, Shen FF, Harwerth RS, Crawford MLJ, Smith EL, Whitetree A: Glutathione content is altered in Muller cells of monkey eyes with experimental glaucoma. Neurosc Lett 2004;364:7-10.

19 Kilic U, Kilic E, Jarve A, Guo ZY, Spudich A, Bieber K, Barzena U, Bassetti CL, Marti HH, Hermann DM: Human vascular endothelial growth factor protects axotomized retinal ganglion cells in vivo by activating ERK-1/2 and Akt pathways. J Neurosc 2006;26:12439-12446.

20 Tolentino MJ, McLeod DS, Taomoto M, Otsuji T, Adamis AP, Lutty GA: Pathologic features of vascular endothelial growth factor-induced retinopathy in the nonhuman primate. Am J Ophthalmol 2002;133:373385 .

-21 Bentivoglio M, Mazzarello P: The history of radial glia. Brain Res Bull 1999;49:305-315.

22 Gotz M, Hartfuss E, Malatesta P: Radial glial cells as neuronal precursors: a new perspective on the correlation of morphology and lineage restriction in the developing cerebral cortex of mice. Brain Res Bull 2002;57:777-788.

23 Gregg CT, Chojnacki AK, Weiss S: Radial glial cells as neuronal precursors: The next generation? J Neurosci Res 2002;69:708-713.

24 Schmidt C, McGonnell I, Allen S, Patel K: The role of Wnt signalling in the development of somites and neural crest. Adv Anat Embryol Cell Biol 2008;195:1-64.

25 Nusse R, Fuerer C, Ching W, Harnish K, Logan C, Zeng A, ten Berge D, Kalani Y: Wnt signaling and stem cell control. Cold Spring Harb Symp Quant Biol 2008;73:59-66.

-26 Zechner D, Fujita Y, Hulsken J, Muller T, Walther I, Taketo MM, Crenshaw EB 3rd, Birchmeier W, Birchmeier C: Beta-catenin signals regulate cell growth and the balance between progenitor cell expansion and differentiation in the nervous system. Dev Biol 2003;258:406-418.

-27 Pinson KI, Brennan J, Monkley S, Avery BJ, Skarnes WC: An LDL-receptor-related protein mediates Wnt signalling in mice. Nature 2000;407:535-538. 


\section{Cellular Physiology $\quad$ Cell Physiol Biochem 2014;34:1109-1124 and Biochemistry \\ Chen/Li/Xu/Yin: $\mathrm{NaIO}_{3}$ Influences the Stemness of Radial Glial Cells}

28 Semenov MV, Tamai K, Brott BK, Kuhl M, Sokol S, He X: Head inducer Dickkopf-1 is a ligand for Wnt coreceptor LRP6. Curr Biol 2001;11:951-961.

29 Xu H, Huang W, Wang Y, Sun W, Tang J, Li D, Xu P, Guo L, Yin ZQ, Fan X: The function of BMP4 during neurogenesis in the adult hippocampus in Alzheimer's disease. Ageing Res Rev 2013;12:157-164.

-30 Vivien D, Ali C: Transforming growth factor-beta signalling in brain disorders. Cytokine Growth Factor Rev 2006;17:121-128.

-31 Shi Y, Massague J: Mechanisms of TGF-beta signaling from cell membrane to the nucleus. Cell 2003;113:685-700.

-32 Stipursky J, Gomes FC: TGF-beta1/SMAD signaling induces astrocyte fate commitment in vitro: implications for radial glia development. Glia 2007;55:1023-1033.

33 Li H, Babiarz J, Woodbury J, Kane-Goldsmith N, Grumet M: Spatiotemporal heterogeneity of CNS radial glial cells and their transition to restricted precursors. Dev Biol 2004;271:225-238.

-34 Li H, Chang YW, Mohan K, Su HW, Ricupero CL, Baridi A, Hart RP, Grumet M: Activated Notch1 maintains the phenotype of radial glial cells and promotes their adhesion to laminin by upregulating nidogen. Glia 2008;56:646-658.

- 35 Li H, Han YR, Bi C, Davila J, Goff LA, Thompson K, Swerdel M, Camarillo C, Ricupero CL, Hart RP, Plummer MR, Grumet M: Functional differentiation of a clone resembling embryonic cortical interneuron progenitors. Dev Neurobiol 2008;68:1549-1564.

-36 Jho EH, Zhang T, Domon C, Joo CK, Freund JN, Costantini F: Wnt/beta-catenin/Tcf signaling induces the transcription of Axin2, a negative regulator of the signaling pathway. Mol Cell Biol 2002;22:1172-1183.

37 L'Episcopo F, Tirolo C, Testa N, Caniglia S, Morale MC, Impagnatiello F, Pluchino S, Marchetti B: Aginginduced Nrf2-ARE pathway disruption in the subventricular zone drives neurogenic impairment in parkinsonian mice via PI3K-Wnt/beta-catenin dysregulation. J Neurosc 2013;33:1462-1485.

-38 Gage FH: Mammalian neural stem cells. Science 2000;287:1433-1438.

-39 de Jong PT: Age-related macular degeneration. N Engl J Med 2006;355:1474-1485.

40 Blacharski P: Fundus flavimaculatus; in Newsome DA (ed): Retinal Dystrophies and Degenerations. New York, Raven Press, 1988, pp 135-159.

41 Noell WK: Experimentally induced toxic effects on structure and function of visual cells and pigment epithelium. Am J Ophthalmol 1953;36:103-116.

42 Machalinska A, Lubinski W, Klos P, Kawa M, Baumert B, Penkala K, Grzegrzolka R, Karczewicz D, Wiszniewska B, Machalinski B: Sodium iodate selectively injuries the posterior pole of the retina in a dosedependent manner: morphological and electrophysiological study. Neurochem Res 2010;35:1819-1827.

43 L'Episcopo F, Tirolo C, Testa N, Caniglia S, Morale MC, Deleidi M, Serapide MF, Pluchino S, Marchetti B: Plasticity of subventricular zone neuroprogenitors in MPTP (1-methyl-4-phenyl-1,2,3,6tetrahydropyridine) mouse model of Parkinson's disease involves cross talk between inflammatory and Wnt/beta-catenin signaling pathways: functional consequences for neuroprotection and repair. J Neurosci 2012;32:2062-2085.

44 Temple S: The development of neural stem cells. Nature 2001;414:112-117.

45 Mira H, Andreu Z, Suh H, Lie DC, Jessberger S, Consiglio A, San Emeterio J, Hortiguela R, Marques-Torrejon MA, Nakashima K, Colak D, Gotz M, Farinas I, Gage FH: Signaling through BMPR-IA regulates quiescence and long-term activity of neural stem cells in the adult hippocampus. Cell Stem Cell 2010;7:78-89.

-46 Stipursky J, Francis D, Gomes FC: Activation of MAPK/PI3K/SMAD pathways by TGF-beta(1) controls differentiation of radial glia into astrocytes in vitro. Dev Neurosci 2012;34:68-81. 